\title{
THE IMPACT OF PATENTS AND R\&D COOPERATION ON R\&D INVESTMENTS IN A DIFFERENTIATED GOODS INDUSTRY
}

Adam Karbowski, Jacek Prokop

\section{Abstract}

In this paper, we consider the impact of patents and $R \& D$ cooperation on $R \& D$ investments in the oligopolistic industry with differentiated products. Four types of firms' conduct are investigated: $R \& D$ competition without patents, R\&D competition with patent protection, $R \& D$ cooperation, and the full industry cooperation. The obtained results suggest that patents do not necessarily promote $R \& D$ investments due to the existence of so called tournament effects. $R \& D$ cooperation stimulates $R \& D$ investments, but $R \& D$ cooperation provides sufficient incentives to create a full industry cartel. Such a cartel works to the detriment of consumers. Our analysis led us to the conclusion that for a relatively low level of $R \& D$ spillovers, the policy-makers should promote $R \& D$ competition without patent protection among oligopolistic firms. For a relatively high level of $R \& D$ spillovers, $R \& D$ cooperation enhances innovation, but the regulator should monitor the market for probable collusion.

Keywords: research and development, investments, patents, cooperation, differentiated goods

\section{JEL classification code: $\mathrm{O3}$}

\section{INTRODUCTION}

One of the fundamental tasks of the modern innovation policy is to promote private $R \& D$ investments (cf., e.g., Becker 2015; Pejic-Bach et al. 2015; Schot and Steinmueller 2018; Mahmutaj and Krasniqi 2020). The private $R \& D$ investments play a critical role in explaining economic growth (Becker 2015). The latter statement is supported by a large body of empirical and theoretical literature (see, e.g., Romer 1986; Grossman and Helpman 1991; Howitt and Aghion 1998; Kafouros 2005; O'Mahony and Vecchi 2009; Bravo-Ortega and Marin 2011; Bezdrob and Šunje 2014; Becker 2015). Promoting private R\&D investments is though a tricky task, since the private R\&D constitutes a public goods' problem (Nelson 1959; Arrow 1962; Becker 2015). The private $R \& D$ is non-rival and non-excludable, thus leading to the discrepancy in the private and social rate of return. The firms investing in R\&D are not capable of appropriating all the returns from the
Adam Karbowski, PhD in Economics Assistant Professor

Department of Business Economics Collegium of World Economy, SGH Warsaw School of Economics E-mail: adam.karbowski@sgh.waw.pl.

Jacek Prokop (corresponding author)

Professor

Department of Business Economics

Collegium of World Economy, SGH Warsaw School of Economics E-mail: jacek.prokop@sgh.waw.pl Address: Al. Niepodległości 162, 02-554 Warsaw, Poland 
investments which generate the knowledge spillovers (externalities) to the benefit of others (competitors, suppliers, buyers, universities, to name a few). The discrepancy in the private and social rate of return results in the private underinvestment in R\&D. Thus, the public policy finds it both necessary and beneficial to promote private investments in R\&D.

Based on Czarnitzki and Toole (2006), Lokshin and Mohnen (2012), Becker (2015), Schot and Steinmueller (2018), Bloom, van Reenen and Williams (2019), and Stojčić, Srhoj and Coad (2020), the modern innovation policy offers the following instruments to promote the private $R \& D$ investments (for a detailed presentation, see the next section):

1. R\&D tax credits and direct grants or subsidies (including cost-sharing arrangements, tax exemptions, provision of financial guarantees),

2. support of the university research and technology transfer from public labs,

3. patents,

4. R\&D cooperation,

5. public procurement for innovation.

In this paper, we focus on the two instruments of innovation policy, i.e., patent protection and R\&D cooperation. The reason for placing the emphasis on those two instruments is the current economic debate on the interactions between patents and cooperative R\&D agreements, and in particular, on their complementarity or substitutability (cf., e.g., Penin 2005; 2012; Somaya 2012; Boldrin and Levine 2013; Comino et al. 2019).

The primary aim of this paper is to investigate the impact of patents and R\&D cooperation on R\&D investments made by firms. Since most of R\&D investments refer to product markets with differentiated goods (Flath 2012; Rant and Černe 2017; Karbowski 2019), we consider a differentiated goods industry. In particular, we compare the R\&D investments made by firms under the following market structures: R\&D competition without patents, R\&D competition with patent protection, $R \& D$ cooperation, and full industry cooperation. As a secondary goal, we investigate the firms' incentives to follow patenting strategy or cooperative strategy. To this end, we compute the firms' profits corresponding to the four market structures mentioned above.

Based on the reviewed literature (for a detailed presentation, see the next section), we formulate the following predictions (cf., figure 1). First, we expect that in a differentiated goods industry, patents augment $R \& D$ investments made by firms. Second, we expect that in a differentiated goods industry, $R \& D$ cooperation increases R\&D investments undertaken by firms. Third, we expect that in a differentiated goods industry, firms' profits are the highest when the full industry cooperation (cartelization) takes place.

Figure 1. The conceptual model and theoretical predictions.

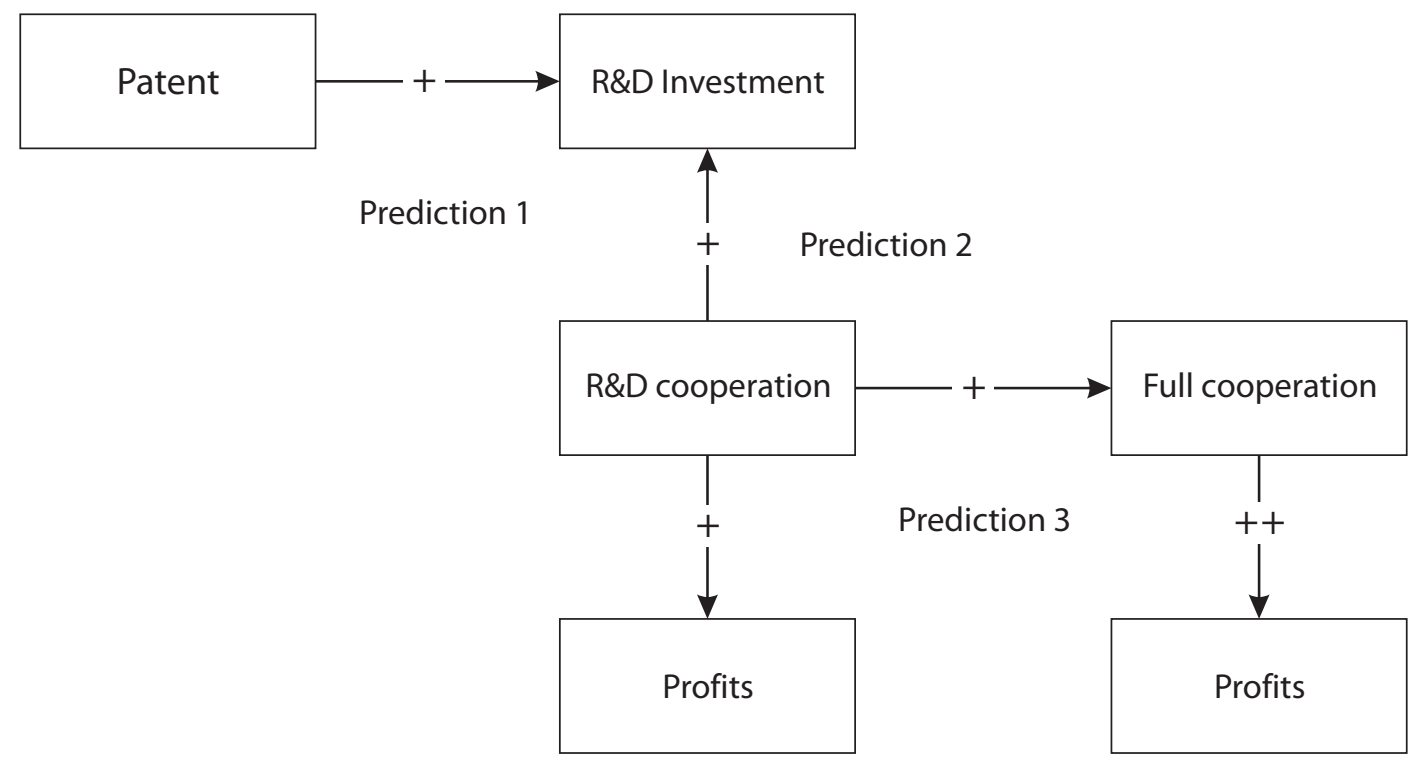

Source: own elaboration.

" + " - positive impact

"++" - stronger than "+" positive impact 
The paper is organized as follows. After the literature review, we consider the reference case of $R \& D$ competition without patents. Then, we investigate the scenario of R\&D competition with patent protection. Next, we analyze R\&D cooperation, and further, we consider a case of full industry cooperation (cartelization). The subsequent section discusses the obtained results. Conclusions follow and close the paper.

\section{LITERATURE REVIEW}

The modern innovation policy offers supply-side (push) and demand-side (pull) instruments (Petrin 2018) to promote private $R \& D$ investments. To the first group belong R\&D tax credits and direct subsidies, support of the university research and technology transfer, patents, and R\&D cooperation. Public procurement for innovation constitutes, in turn, the flagship demand-side instrument.

R\&D tax credits and direct subsidies (Besley and Suzumura 1992; Bagwell and Staiger 1994) belong to the public finance tools which allow to secure the economic activity that generates positive externalities. The "older" economic literature (literature published prior to 2000) arrived at the conclusion that $R \& D$ tax credits as a supply-side (push) policy instrument (Petrin 2018) exert a significant positive impact on private R\&D investments (see, Hall and van Reenen 2000 , for a review), though the strength of that impact exhibits a relatively high variability and depends on the strategic substitutability of outputs and cost-reducing R\&D investments (Besley and Suzumura 1992). Bagwell and Staiger (1994) show that when R\&D reduces costs of production, there exists a strategic basis for R\&D subsidies and a corrective incentive to tax R\&D. As Leahy and Neary (1997) observe, R\&D subsidies are justified except when R\&D spillovers are low and firms' actions are strategic substitutes.

The "newer" literature confirms the positive empirical relationship between the R\&D tax credits and private R\&D investments (Baghana and Mohnen 2009; Czarnitzki et al. 2011; Hodžić 2012; Mulkay and Mairesse 2013; Becker 2015; Chang 2018), and is unanimous in assessing the strength of the above effect. The reported negative elasticity of private $R \& D$ investment with respect to the user cost is around unity. As regards the impact of direct subsidies on private R\&D investment, the relevant literature did not reach a compromise. Some of the existing studies report a negative relationship between the direct subsidy and private R\&D investment (the crowding out effect), cf., e.g., David et al. 2000; Garcia-Quevedo 2004; Becker 2015. The other reports point to the positive relationship between direct subsidies and private $R \& D$ investments (the additionality effect), cf., e.g., Duguet 2004; Carboni 2011; Bloch and Graversen 2012; Becker 2015.

Another supply-side instrument, the university research and technology transfer, can effectively support private R\&D. As Nelson (1986) observed, the university research rarely generates new technologies, but often it enhances technological opportunities and the productivity of private R\&D (Becker 2015). There is a large body of empirical literature that reports the positive impact of the university research on the private R\&D investments (cf., e.g., Jaffe 1989; Woodward et al. 2006; Karlsson and Andersson 2009; Abramovsky and Simpson 2011; Becker 2015; Scandura 2016; Guerrero et al. 2019). As Becker (2015) notes, improving the university research and facilitating spillovers to the private sector effectively raise R\&D investments made by firms. The knowledge spillovers from universities play a critical role in the development of hightech industries. The government via the targeted support of the university research can thus speed up the progress in the selected high-tech industries. Such a policy can bring about more breakthrough innovations (Harryson et al. 2007).

As Czarnitzki and Toole (2006) observe, patents grant inventors temporary monopoly rights which allow the inventors to appropriate a greater share of the returns resulting from the invention which generates positive knowledge externalities. The patent mechanism reduces the discrepancy in the private and social rate of return from the $R \& D$ investment, thus patents are believed to directly promote and push private innovation (see, Nordhaus 1969 or Mazzoleni and Nelson 1998, for a wider discussion). On the other hand, some economists suggest that patent protection can in fact reduce private $R \& D$ due to the existence of so called tournament effects (Chowdhury 2005). Tournament effect adversely influences R\&D incentives if firms simultaneously undertake similar activities leading to the given patent (Che and Yang 2009). Delbono and Denicolo (1991) show in a one-shot non-cooperative game that increasing rivalry in a patent race can decrease the individual R\&D investments made by oligopolistic firms and lead to the underinvestment from the social welfare viewpoint.

Innovation policy-makers can promote R\&D cooperation (a supply-side instrument) between firms to stimulate private R\&D investments (Cassiman 2000; Barajas et al. 2012). As d'Aspremont and Jacquemin (1988) show, firm's R\&D investments are higher under $R \& D$ cooperation compared with R\&D competition, if the level of knowledge spillovers in the industry is sufficiently large. Kamien and co-authors (1992), and 
Kamien and Zang (2000) confirm in a more general model of oligopoly that firm's R\&D investments under $R \& D$ cooperation dominate those under R\&D competition, if the level of spillovers is large enough. The latter result has been also confirmed empirically, see, e.g., Becker and Dietz (2004) or Aschhoff and Schmidt (2008). In the presence of positive knowledge externalities, the higher appropriability of R\&D returns under cooperative R\&D compared with the competitive $R \& D$ enhances corporate $R \& D$ investments and innovation under $R \& D$ cooperation compared with R\&D competition (Czarnitzki et al. 2007; Becker 2015; Belderbos et al. 2018). Petit and Tolwinski (1999) show that the creation of R\&D cooperation may be beneficial both from a private and social welfare point of view. The drawback of R\&D cooperation is however the risk that $R \& D$ cooperation can provide sufficiently strong incentives to form a cartel on the final product market ( $R \& D$ cooperation can be a stepping stone to the full industry cartel, cf., Martin 2006; Miyagiwa 2009). If R\&D spillovers are maximal, collusive market outcomes become very likely (Kräkel 2004).

Public procurement for innovation (PPI) is a demand-side (pull) instrument (Petrin 2018; Stojčić et al. 2020) which can effectively reduce the costs of learning and product enhancing while offering scale economies to firms. As a result, firms can substantially reduce their costs of developing and commercialising new products or technologies (Stojčić et al. 2020). Further, PPI can help governments increase a demand for innovations which address societal needs and grand challenges (e.g., climate change, energy efficiency, food and health, sustainable transport; Stojčić et al. 2020).

\section{R\&D COMPETITION}

We consider an industry composed of two companies, denoted 1 and 2. They manufacture $q_{1}$ and $q_{2}$ units of a heterogeneous product, respectively. The market demand for the product is given by the inverse demand function in the following form:

$$
p_{i}=a-q_{i}-s q_{j}
$$

where $p_{i}$ denotes the market price of the final good offered by firm $i, q_{i}$ is the volume produced by firm $i, a$ is the demand intercept (the larger value corresponds with the larger product market), and $s(0 \leq s \leq 1)$ is the substitutability parameter. Observe that both goods are perfect substitutes when $s=1$, and the firms become monopolists when $s=0$.

The total manufacturing cost of each company is characterized by the following quadratic function (the justification of such specification can be found, e.g., in Hattori and Tanaka 2019):

$$
\frac{q_{i}^{2}}{c}
$$

where $c$ is a given parameter of an initial efficiency of firm $i$. It is assumed that the entry barriers to the industry are too high for new enterprises to enter.

The model proceeds in two stages, as in Besley and Suzumura (1992). In the first, R\&D, stage, both companies simultaneously and independently decide about their levels of R\&D investments, $x_{i}$. These decisions affect the functions of total manufacturing costs of each firm. The costs of R\&D investments have a form of quadratic function:

$$
\gamma \frac{x_{i}^{2}}{2}
$$

where $y(y>0)$ is a given parameter. In the second, product market, stage, the companies compete in the final product market according to the Cournot model.

First, we consider the case in which the invention resulting from the R\&D works is not protected by the patent (R\&D competition without patents). When both firms invest in R\&D, the cost of manufacturing for firm $i$ is given by the following function:

$$
C_{i}\left(q_{i}, x_{i}, x_{j}\right)=\frac{q_{i}^{2}}{c+x_{i}+\beta x_{j}},
$$

where $x_{i}$ denotes the amount of R\&D investments made by the company $i$, and $x_{j}$ denotes the amount of R\&D investments made by the competitor, firm $j$. Parameter $\beta(0 \leq \beta \leq 1)$ determines the size of R\&D spillovers, i.e., the benefits for a given company obtained as a result of research undertaken by the competitor.

The profit of firm $i$ may be written in the following form:

$$
\pi_{i}=\left(a-q_{i}-s q_{j}\right) q_{i}-\frac{q_{i}^{2}}{c+x_{i}+\beta x_{j}}-\gamma \frac{x_{i}^{2}}{2} .
$$

The first order conditions with respect to $q_{i}$ generate the level of output that maximizes the profit of company $i$ :

$$
q_{i}=\frac{a\left(2+\frac{2}{c+\beta x_{1}+x_{2}}-s\right)}{4\left(1+\frac{1}{c+\beta x_{1}+x_{2}}\right)\left(1+\frac{1}{c+x_{1}+\beta x_{2}}\right)-s^{2}} .
$$

Observe that the production levels $q_{1}$ and $q_{2}$ given by (6) constitute the Cournot-Nash equilibrium for given levels of R\&D investments, $x_{1}$ and $x_{2}$.

After substituting (6) into (5), we obtain the profits 
of each firm, $\pi_{1}$ and $\pi_{2}$, as functions of R\&D investments, $x_{1}$ and $x_{2}$ :

$$
\pi_{i}\left(x_{1}, x_{2}\right) \quad(i=1,2) .
$$

In the first stage, when firms simultaneously decide about their R\&D activities, the Nash equilibrium strategies are obtained as a solution to the following set of two equations with two unknowns, $x_{1}$ and $x_{2}$ :

$$
\frac{\partial \pi_{i}}{\partial x_{i}}=0 \quad(i=1,2) .
$$

Denote the solution to the above system by $x_{1}^{*}$ and $x_{2}^{*}$. By substituting $x_{i}^{*}$ for $x_{i}$ into (6), and (7), we obtain the equilibrium output levels, $q_{i}^{*}$, and the equilibrium profits, $\pi_{i}^{*}$. Since we consider a symmetric equilibrium, we have $x_{1}^{*}=x_{2}^{*}, q_{1}^{*}=q_{2}^{*}$, and $\pi_{1}^{*}=\pi_{2}^{*}$.

We use numerical analysis in order to show possibilities of certain outcomes. In this paper, we will restrict our considerations to the case when three parameters of the model are: $a=100, c=1, y=3$. The results of the calculations for $s=0.5$ and various levels of parameter $\beta$ are given in table 1 .

Table 1. R\&D competition - the case of no patents for $a=100, c=1, y=3, s=0.5$, and $\beta \in[0,1]$

\begin{tabular}{|c|c|c|c|c|}
\hline $\boldsymbol{\beta}$ & $\boldsymbol{x}_{\boldsymbol{i}}^{*}$ & $\boldsymbol{q}_{\boldsymbol{i}}^{*}$ & $\boldsymbol{p}_{\boldsymbol{i}}^{*}$ & $\boldsymbol{\pi}_{\boldsymbol{i}}^{*}$ \\
\hline 0.0 & 7.22795 & 36.4555 & 45.3168 & 1412.16 \\
\hline 0.1 & 6.70392 & 36.5120 & 45.2320 & 1424.90 \\
\hline 0.2 & 6.24431 & 36.5566 & 45.1651 & 1435.25 \\
\hline 0.3 & 5.83592 & 36.5909 & 45.1136 & 1443.74 \\
\hline 0.4 & 5.46894 & 36.6161 & 45.0759 & 1450.76 \\
\hline 0.5 & 5.13587 & 36.6329 & 45.0506 & 1456.59 \\
\hline 0.6 & 4.83085 & 36.6420 & 45.0371 & 1461.43 \\
\hline 0.7 & 4.54923 & 36.6435 & 45.0348 & 1465.44 \\
\hline 0.8 & 4.28724 & 36.6376 & 45.0436 & 1468.73 \\
\hline 0.9 & 4.04175 & 36.6242 & 45.0637 & 1471.37 \\
\hline 1.0 & 3.81013 & 36.6031 & 45.0954 & 1473.43 \\
\hline
\end{tabular}

Source: own calculations

From table 1 , it follows that the R\&D investments of each firm decline with the growing scale of R\&D spillovers. The supply of the final product achieves its maximum for the parameter $\beta=0.7$, which results in the lowest level of the market price. However, the profits of each firm are higher when the extent of R\&D externalities is greater.

Now, we look at the effect of changes in the substitutability (parameter $s$ ) on the behavior of firms. Table 2 reports the Cournot equilibrium for various levels of $s$, and the R\&D spillover parameter $\beta=0.3$.
Table 2. R\&D competition - the case of no patents for $a=100, c=1, y=3, \beta=0.3$, and $s \in[0,1]$

\begin{tabular}{|c|c|c|c|c|}
\hline $\boldsymbol{s}$ & $\boldsymbol{x}_{\boldsymbol{i}}^{*}$ & $\boldsymbol{q}_{\boldsymbol{i}}^{*}$ & $\boldsymbol{p}_{\boldsymbol{i}}^{*}$ & $\boldsymbol{\pi}_{\boldsymbol{i}}^{*}$ \\
\hline 0.0 & 6.90939 & 45.4472 & 54.5528 & 2200.75 \\
\hline 0.1 & 6.62133 & 43.3244 & 52.3431 & 2006.61 \\
\hline 0.2 & 6.37354 & 41.4012 & 50.3185 & 1837.72 \\
\hline 0.3 & 6.16202 & 39.6517 & 48.4528 & 1689.79 \\
\hline 0.4 & 5.98364 & 38.0543 & 46.7240 & 1559.38 \\
\hline 0.5 & 5.83592 & 36.5909 & 45.1136 & 1443.74 \\
\hline 0.6 & 5.71702 & 35.2462 & 43.6061 & 1340.59 \\
\hline 0.7 & 5.62568 & 34.0069 & 42.1882 & 1248.11 \\
\hline 0.8 & 5.56123 & 32.8620 & 40.8483 & 1164.75 \\
\hline 0.9 & 5.52355 & 31.8018 & 39.5767 & 1089.22 \\
\hline 1.0 & 5.51329 & 30.8178 & 38.3644 & 1020.43 \\
\hline
\end{tabular}

Source: own calculations

From table 2, it follows that the size of R\&D investments declines monotonically together with an increasing degree of substitutability (increasing parameter $s$ ).

Together with a decline in product differentiation, we observe a decreasing level of profits earned by the duopolists. The highest profits are obtained when product differentiation is maximal, i.e., $s=0$; the lowest profits are observed when products are homogenous, i.e., $s=1$. Also, the level of prices is lowest when the product differentiation is minimized.

Next, we consider R\&D competition with patent protection. A patent obtained by firm $i$ reduces its manufacturing costs according to the formula (4). However, a patent obtained by firm $j$ (the competitor), does not allow firm $i$ to use the patented technology, and firm $i$ manufactures at the costs given by formula (2). Since the firms are identical, we assume that the chance of patenting by each of them is 0.5 .

Thus, in the case with patent protection, the expected profit of a duopolist $i$ is given as:

$$
\pi_{i}^{e}=p q_{i}-\gamma \frac{x_{i}^{2}}{2}-\left(\frac{1}{c+x_{i}+\beta x_{j}}+\frac{1}{c}\right) \frac{q_{i}^{2}}{2} .
$$

The optimal level of supply by firm $i$ is:

$$
q_{i}=\frac{a\left(2+\frac{2}{c}+\frac{2}{c+\beta x_{1}+x_{2}}-s\right)}{4\left(1+\frac{1}{c}+\frac{1}{c+\beta x_{1}+x_{2}}\right)\left(1+\frac{1}{c}+\frac{1}{c+x_{1}+\beta x_{2}}\right)-s^{2}} .
$$

After substituting (10) to the expression (9), we obtain the equilibrium expected profit of firm $i$ (this profit is a function of $R \& D$ investments). The optimal levels of R\&D investment are calculated as a solution to the following set of equations: $\frac{\partial \pi_{i}^{e}}{\partial x_{i}}=0(i=1,2)$. 
Denote this solution as $\hat{x}_{1}$ and $\hat{x}_{2}$. The optimal levels of production are denoted as $\hat{q}_{1}$ and $\hat{q}_{2}$, and optimal levels of expected profits are called $\hat{\pi}_{1}^{e}$ and $\hat{\pi}_{2}^{e}$. Since our firms are identical, we consider a symmetric case, $\hat{x}_{1}=\hat{x}_{2}, \hat{q}_{1}=\hat{q}_{2}$ and $\hat{\pi}_{1}^{e}=\hat{\pi}_{2}^{e}$.

Table 3 provides the results of numerical analysis for the case with patent protection and for the previously selected set of parameter values.

Table 3. R\&D competition - the case of patent protection for $a=100, c=1, y=3, s=0.5$, and $\beta \in[0,1]$

\begin{tabular}{|c|c|c|c|c|}
\hline $\boldsymbol{\beta}$ & $\widehat{\boldsymbol{x}}_{\boldsymbol{i}}$ & $\widehat{\boldsymbol{q}}_{\boldsymbol{i}}$ & $\widehat{\boldsymbol{p}}_{\boldsymbol{i}}$ & $\widehat{\boldsymbol{\pi}}_{\boldsymbol{i}}^{\boldsymbol{e}}$ \\
\hline 0.0 & 4.61019 & 20.5910 & 69.1135 & 891.671 \\
\hline 0.1 & 4.31294 & 20.6263 & 69.0605 & 897.052 \\
\hline 0.2 & 4.05374 & 20.6567 & 69.0149 & 901.512 \\
\hline 0.3 & 3.82500 & 20.6831 & 68.9754 & 905.261 \\
\hline 0.4 & 3.62105 & 20.7060 & 68.9410 & 908.447 \\
\hline 0.5 & 3.43760 & 20.7260 & 68.9110 & 911.181 \\
\hline 0.6 & 3.27130 & 20.7434 & 68.8849 & 913.545 \\
\hline 0.7 & 3.11951 & 20.7585 & 68.8622 & 915.600 \\
\hline 0.8 & 2.98012 & 20.7716 & 68.8425 & 917.395 \\
\hline 0.9 & 2.85140 & 20.7829 & 68.8256 & 918.968 \\
\hline 1.0 & 2.73195 & 20.7926 & 68.8111 & 920.350 \\
\hline
\end{tabular}

Source: own calculations

It follows from table 3 that the R\&D investments decline with the growing scale of R\&D spillovers. This result is similar to the case of no patent protection. However, the increasing size of R\&D externalities induces here the larger supply of the final product and lower level of the market price, which is different from the case of no patent protection. The resulting profits of firms are higher when the extent of R\&D externalities is greater.

Next, we analyze the impact of changes in the substitutability parameter on the behavior of firms. The Cournot equilibrium for the R\&D spillover parameter $\beta=0.3$, and various levels of $s$ are shown in table 4 .

Based on table 4, the level of R\&D investments is declining when the product differentiation becomes lower (increasing parameter s). A decline in product differentiation reduces the supply and the profits of companies. It is not surprising that the firms enjoy the highest profits when product differentiation is maximal, i.e., $s=0$. The consumers enjoy the lowest prices when the product differentiation is minimized, i.e., $s=1$. These results are similar to the case of no patent protection.
Table 4. R\&D competition - the case of patent protection for $a=100, c=1, y=3, s=0.5, \beta=0.3$ and $s \in[0,1]$

\begin{tabular}{|c|c|c|c|c|}
\hline $\boldsymbol{S}$ & $\widehat{\boldsymbol{x}}_{\boldsymbol{i}}$ & $\widehat{\boldsymbol{q}}_{\boldsymbol{i}}$ & $\widehat{\boldsymbol{p}}_{\boldsymbol{i}}$ & $\widehat{\boldsymbol{\pi}}_{\boldsymbol{i}}^{\boldsymbol{e}}$ \\
\hline 0.0 & 4.23890 & 23.2170 & 76.7830 & 1133.900 \\
\hline 0.1 & 4.14300 & 22.6593 & 75.0747 & 1081.550 \\
\hline 0.2 & 4.05402 & 22.1289 & 73.4453 & 1032.830 \\
\hline 0.3 & 3.97157 & 21.6239 & 71.8889 & 987.396 \\
\hline 0.4 & 3.89533 & 21.1425 & 70.4006 & 944.962 \\
\hline 0.5 & 3.82500 & 20.6831 & 68.9754 & 905.261 \\
\hline 0.6 & 3.76031 & 20.2443 & 67.6090 & 868.057 \\
\hline 0.7 & 3.70103 & 19.8249 & 66.2976 & 833.140 \\
\hline 0.8 & 3.64696 & 19.4236 & 65.0375 & 800.320 \\
\hline 0.9 & 3.59791 & 19.0393 & 63.8252 & 769.426 \\
\hline 1.0 & 3.55373 & 18.6711 & 62.6579 & 740.305 \\
\hline
\end{tabular}

Source: own calculations

\section{$R \& D$ COOPERATION}

In this section, we consider the cooperation of firms in the R\&D stage, but not on the final product market (the case of R\&D cooperation, often called the R\&D cartel, see, e.g., Kamien et al. 1992; Kamien and Zang 2000; Karbowski 2019). The firms are assumed to behave non-cooperatively as Cournot players in the final product market. When deciding about the levels of $R \& D$ investments, the companies maximize the joint profit of the R\&D cartel, i.e., $\pi\left(x_{1}, x_{2}\right)=\pi_{1}+\pi_{2}$.

Since we focus on the symmetric equilibria, the optimal level of R\&D investment of an individual firm amounts to $\tilde{x}_{1}=\tilde{x}_{2}$, the optimal supply of the final product equals $\tilde{q}_{1}=\tilde{q}_{2}$, the optimal market price equals $\tilde{p}_{1}=\tilde{p}_{2}$, and the optimal level of profit is $\tilde{\pi}_{1}=\tilde{\pi}_{2}$.

Table 5 illustrates the results of a numerical analysis in the case of an R\&D cartel for the previously selected set of parameter values.

It follows from table 5 that an increasing level of $R \& D$ spillovers causes a decline of $R \& D$ investments and of the price of the final product, but induces an increase of supply and profits of firms. This result is similar to the case of R\&D competition under patent protection. 
Table 5. R\&D cartel - equilibrium for $a=100, c=1, y=3$, $s=0.5$, and $\beta \in[0,1]$

\begin{tabular}{|c|c|c|c|c|}
\hline $\boldsymbol{\beta}$ & $\tilde{\boldsymbol{x}}_{\boldsymbol{i}}$ & $\widetilde{\boldsymbol{q}}_{\boldsymbol{i}}$ & $\tilde{\boldsymbol{p}}$ & $\widetilde{\boldsymbol{\pi}}_{\boldsymbol{i}}$ \\
\hline 0.0 & 5.84969 & 35.8168 & 46.2748 & 1418.80 \\
\hline 0.1 & 5.72382 & 36.0475 & 45.9287 & 1428.38 \\
\hline 0.2 & 5.60803 & 36.2484 & 45.6274 & 1436.76 \\
\hline 0.3 & 5.50107 & 36.4251 & 45.3623 & 1444.17 \\
\hline 0.4 & 5.40187 & 36.5822 & 45.1268 & 1450.77 \\
\hline 0.5 & 5.30953 & 36.7228 & 44.9159 & 1456.71 \\
\hline 0.6 & 5.22328 & 36.8495 & 44.7257 & 1462.08 \\
\hline 0.7 & 5.14246 & 36.9646 & 44.5531 & 1466.97 \\
\hline 0.8 & 5.06651 & 37.0695 & 44.3957 & 1471.43 \\
\hline 0.9 & 4.99494 & 37.1657 & 44.2514 & 1475.54 \\
\hline 1.0 & 4.92734 & 37.2543 & 44.1185 & 1479.33 \\
\hline
\end{tabular}

Source: own calculations

Table 6 provides the effect of changes in product differentiation on the behavior of firms in the case of an $R \& D$ cartel for the selected set of parameter values.

Table 6. R\&D cartel - equilibrium for $a=100, c=1, y=3$, $\beta=0.3$, and $s \in[0,1]$

\begin{tabular}{|c|c|c|c|c|}
\hline $\boldsymbol{S}$ & $\tilde{\boldsymbol{x}}_{\boldsymbol{i}}$ & $\widetilde{\boldsymbol{q}}_{\boldsymbol{i}}$ & $\widetilde{\boldsymbol{p}}$ & $\widetilde{\boldsymbol{\pi}}_{\boldsymbol{i}}$ \\
\hline 0.0 & 7.62840 & 45.8043 & 54.1957 & 2202.93 \\
\hline 0.1 & 7.12752 & 43.5764 & 52.0660 & 2007.67 \\
\hline 0.2 & 6.66963 & 41.5487 & 50.1416 & 1838.08 \\
\hline 0.3 & 6.24900 & 39.6950 & 48.3965 & 1689.82 \\
\hline 0.4 & 5.86082 & 37.9933 & 46.8094 & 1559.44 \\
\hline 0.5 & 5.50107 & 36.4251 & 45.3623 & 1444.17 \\
\hline 0.6 & 5.16631 & 34.9749 & 44.0402 & 1341.74 \\
\hline 0.7 & 4.85364 & 33.6292 & 42.8304 & 1250.30 \\
\hline 0.8 & 4.56049 & 32.3765 & 41.7222 & 1168.33 \\
\hline 0.9 & 4.28471 & 31.2070 & 40.7067 & 1094.57 \\
\hline 1.0 & 4.02442 & 30.1120 & 39.7760 & 1027.94 \\
\hline
\end{tabular}

Source: own calculations

From table 6, it follows that an increasing differentiation of the final product (lower parameter $s$ ) generates an increase of R\&D investment, a greater supply of the final product, as well as a higher price and profits. These relationships are not different from the case of R\&D competition.

\section{FULL INDUSTRY COOPERATION}

Finally, we move on to the case when both companies created a cartel in the R\&D stage as well as on the final product market. The demand functions and the cost functions are assumed to be the same as in the previous sections.

On the final product market, the companies decide about their production levels $q_{1}$ and $q_{2}$ to maximize the joint profit, given the size of R\&D investments, $x_{1}$ and $x_{2}$ :

$$
\begin{aligned}
& \pi=\left(a-q_{1}-s q_{2}\right) q_{1}-\frac{q_{1}{ }^{2}}{c+x_{1}+\beta x_{2}}-\frac{\gamma x_{1}^{2}}{2}+ \\
& +\left(a-q_{2}-s q_{1}\right) q_{2}-\frac{q_{2}{ }^{2}}{c+x_{2}+\beta x_{1}}-\frac{\gamma x_{2}^{2}}{2} .
\end{aligned}
$$

Since we consider the symmetric equilibria, we have $x_{1}=x_{2}=x$ and $q_{1}=q_{2}=q$, where $q$ is the optimal supply level of each cartel member $\left(\frac{\partial \pi}{\partial q}=0\right)$.

The calculations lead to:

$$
q=\frac{a(c+(1+\beta) x)}{2(1+c+c s+(1+s)(1+\beta) x)} .
$$

After substituting (12) into the inverse demand function given by (1), we obtain the symmetric equilibrium price of the final product:

$$
p_{1}=p_{2}=p=\frac{a(2+c+c s+(1+s)(1+\beta) x)}{2(1+c+c s+(1+s)(1+\beta) x)} .
$$

Next, we can describe the joint cartel profit as a function of R\&D investments of the firms:

$$
\pi=\frac{1}{2}\left(\frac{a^{2}(c+(1+\beta) x)}{1+c+c s+(1+s)(1+\beta) x}-2 \gamma x^{2}\right) .
$$

When the companies form a cartel in the R\&D stage and in the final product market, the symmetric equilibrium takes place when the R\&D investments of each of the firms $(x)$ satisfy the following first order condition for profit maximization:

$$
\frac{\partial \pi}{\partial x}=0 .
$$

Denote the solution to the above equation as $\bar{x}$. After substituting $\bar{x}$ for $x$ into (12), we obtain the production level of each firm; denote it by $\bar{q}=\bar{q}_{1}=\bar{q}_{2}$.

The equilibrium price of the final product offered by each company is obtained by substituting $\bar{x}$. for $x$ into (13); denote it by $\bar{p}$. By substituting $\bar{x}$ for $x$ into (14), we obtain the equilibrium joint profit of the companies; denote it by $\bar{\pi}$. Thus, every company earns:

$$
\bar{\pi}_{1}=\bar{\pi}_{2}=\frac{1}{2} \bar{\pi} \text {. }
$$


Table 7 shows the results of a numerical analysis in the case of full industry cartelization for the selected parameter values.

Table 7. Full industry cartel - equilibrium for $a=100$, $c=1, y=3, s=0.5$, and $\beta \in[0,1]$

\begin{tabular}{|c|c|c|c|c|}
\hline $\boldsymbol{\beta}$ & $\overline{\boldsymbol{x}}_{\boldsymbol{i}}$ & $\overline{\boldsymbol{q}}_{\boldsymbol{i}}$ & $\overline{\boldsymbol{p}}$ & $\overline{\boldsymbol{\pi}}_{\boldsymbol{i}}$ \\
\hline 0.0 & 6.11552 & 30.4778 & 54.2833 & 1467.79 \\
\hline 0.1 & 5.98521 & 30.6399 & 54.0402 & 1478.26 \\
\hline 0.2 & 5.86523 & 30.7805 & 53.8292 & 1487.42 \\
\hline 0.3 & 5.75433 & 30.9040 & 53.6441 & 1495.53 \\
\hline 0.4 & 5.65141 & 31.0134 & 53.4800 & 1502.76 \\
\hline 0.5 & 5.55556 & 31.1111 & 53.3333 & 1509.26 \\
\hline 0.6 & 5.46598 & 31.1991 & 53.2014 & 1515.14 \\
\hline 0.7 & 5.38201 & 31.2788 & 53.0818 & 1520.49 \\
\hline 0.8 & 5.30307 & 31.3514 & 52.9730 & 1525.38 \\
\hline 0.9 & 5.22866 & 31.4178 & 52.8733 & 1529.88 \\
\hline 1.0 & 5.15834 & 31.4789 & 52.7816 & 1534.03 \\
\hline
\end{tabular}

Source: own calculations

Based on table 7, we consider the impact of $R \& D$ spillovers on the equilibrium conduct and performance of firms in the cartelized industry. An increasing level of R\&D externalities induces a decline of $R \& D$ investments and of the final product price, but induces an increase of supply and profits of firms. We have observed this result in the case of R\&D competition under patent protection as well as in the case of an R\&D cartel.

Additional regularities can be observed by changing the degree of product differentiation measured by parameter $s$. Table 8 reports the calculation of the cartel equilibrium for various sizes of $s$, and for $\beta=0.3$.

Table 8. Full industry cartel - equilibrium for $a=100$, $c=1, y=3, \beta=0.3$, and $s \in[0,1]$

\begin{tabular}{|c|c|c|c|c|}
\hline $\boldsymbol{S}$ & $\overline{\boldsymbol{x}}_{\boldsymbol{i}}$ & $\overline{\boldsymbol{q}}_{\boldsymbol{i}}$ & $\overline{\boldsymbol{p}}$ & $\overline{\boldsymbol{\pi}}_{\boldsymbol{i}}$ \\
\hline 0.0 & 7.62840 & 45.8043 & 54.1957 & 2202.93 \\
\hline 0.1 & 7.14330 & 41.7635 & 54.0601 & 2011.64 \\
\hline 0.2 & 6.72546 & 38.3837 & 53.9396 & 1851.34 \\
\hline 0.3 & 6.36105 & 35.5143 & 53.8314 & 1715.02 \\
\hline 0.4 & 6.03991 & 33.0476 & 53.7334 & 1597.66 \\
\hline 0.5 & 5.75433 & 30.9040 & 53.6441 & 1495.53 \\
\hline 0.6 & 5.49839 & 29.0237 & 53.5621 & 1405.84 \\
\hline 0.7 & 5.26744 & 27.3609 & 53.4865 & 1326.43 \\
\hline 0.8 & 5.05780 & 25.8798 & 53.4164 & 1255.62 \\
\hline 0.9 & 4.86647 & 24.5520 & 53.3512 & 1192.08 \\
\hline 1.0 & 4.69102 & 23.3549 & 53.2902 & 1134.74 \\
\hline
\end{tabular}

Source: own calculations
Table 8 shows that the R\&D investments made by a cartel member $(\bar{x})$ are a declining function of the extent of product differentiation (parameter $s$ ). Similarly, a greater extent of R\&D spillovers generates a lower supply of the final product, as well as lower price and profits. These relationships are similar to the case of R\&D competition with or without patent protection (table 2 and table 4) as well as to case of R\&D cartel (table 6).

\section{DISCUSSION}

We may use the equilibria obtained in the previous sections to compare the decisions of firms and their performance under the R\&D competition with or without patent protection, and their behaviour in the case of different types of firms' cooperation.

First, we consider the decisions of companies regarding the investments in R\&D when the final products offered by firms have a medium level of differentiation $(s=0.5)$. Surprisingly, the R\&D investments under R\&D competition without patent protection dominate the R\&D investments under R\&D competition with patent protection. The latter result applies to all values of R\&D spillovers in the industry (cf., table 1 and table 3). Thus, the first prediction based on the literature review is rejected. It means that in a differentiated goods industry, the patent protection does not necessarily promote $R \& D$ investments and corporate innovation. The obtained result can be to some extent explained by the existence of tournament effect. Firms which compete for a patent are aware of the fact that only one firm can win the tournament and obtain a reward in the form of a patent. As a result, the individual $R \& D$ investments decrease if the reward is uncertain and R\&D costs are likely to be sunk. The tournament effect limits the individual R\&D investments under $R \& D$ competition with patent protection. In R\&D competition without patents, the R\&D investments directly translate into cost reductions and improve the competitive positions of firms. Under such market setup, the R\&D investments do not constitute sunk costs.

When we look at the profits of firms under R\&D competition with patents and without them, it turns out that the profits under R\&D competition without patents dominate those under R\&D competition with patents (cf., table 1 and table 3). It means that the enterprises, in the specified market environment, would prefer rivalry without patents to the competition with patent protection. The advantages (in terms of R\&D investments and profits) of R\&D competition without patents over R\&D competition with patents hold for all values of the substitutability parameter (cf., table 2 
and table 4).

Let us now compare the effectiveness of two selected innovation policy instruments, i.e., patents and $R \& D$ cooperation. Based on tables 3-6, we can say that $R \& D$ cooperation dominates (in terms of R\&D investments and profits) R\&D competition supported by patents. The latter claim supports the second prediction and is valid for all values of the substitutability parameter (cf., table 4 and table 6). It seems then that patents and R\&D cooperation cannot be perceived as substitutes in the modern innovation policy. R\&D cooperation dominates patent protection. As Penin $(2005 ; 2012)$ observes, patents can be only a complementary tool in the public policy oriented at promoting innovation which should be based on cooperative $R \& D$ agreements. It seems then that $R \& D$ cooperation (a push policy instrument) exerts a powerful impact on private innovation. Interestingly enough, the effect of enhancing private innovation can be significantly larger in the presence of PPI (a pull policy instrument). As Stojčić et al. (2020) observe, PPI has a large effect on corporate innovation (both at the European and national level), and the highest additionality may be achieved when firms receive both financial support and innovation-oriented public procurement. According to Stojčić et al. (2020), policy-makers aiming to strengthen indigenous innovation capabilities should place stronger emphasis on PPI.

Our study does not measure the impact of the other push policy instruments, i.e., R\&D tax credits, direct grants or subsidies, support of the university research and technology transfer from public labs. The impacts of the above supply-side instruments on private innovation needs to be investigated theoretically (with the use of mathematical models and numerical analysis), compared with the impacts of R\&D cooperation or patents, and classified according to their relative strength or generated additionality effects. However, we set out to do it in another study. Interestingly enough, some empirical papers suggest that subsidies lead to additional R\&D expenditures, but do not lead to additional innovation output (Hashi and Stojčić 2013). R\&D tax credits, in turn, lead to additional innovation output (Czarnitzki et al. 2011). Finally, university technology transfer seems to stimulate break-through, hightech innovation creation and commercialization (for a review, see Audretsch and Caiazza 2016).

Coming back to the obtained results, R\&D cooperation does not dominate $R \& D$ competition without patents (cf., tables 1-2 and 5-6). For relatively low values of R\&D spillovers in the industry (smaller than 0.5 ) and the value of substitutability parameter high enough, $R \& D$ competition without patents brings about larger $R \& D$ investments compared with $R \& D$ cooperation (cf., tables 1-2 and 5-6). For the relatively high values of R\&D spillovers (higher than 0.5), R\&D investments are larger under R\&D cooperation than R\&D competition without patents (cf., tables 1 and 5). The latter supports the second prediction. Thus, it can be claimed that $R \& D$ cartels speed up technological development for a sufficiently large size of R\&D spillovers. Unfortunately, the prices offered by the R\&D cartel members are significantly higher than the price levels expected under R\&D competition.

As regards profits (cf., tables 1-2 and 5-6), R\&D cooperation brings about higher profits compared with $R \& D$ competition without patents for all values of $R \& D$ spillovers in the industry and for all values of the substitutability parameter.

The full industry cartel generates a higher R\&D investment than the firms engaged in $R \& D$ competition under patent protection for any level of product differentiation (cf., tables 3 and 7). Moreover, an industry cartel spends more on R\&D than an R\&D cartel for all values of R\&D spillovers in the industry and as long as $s>0$ (cf., tables 5-8), and both types of cartels have identical spending on R\&D when R\&D spillovers are sufficiently low and products are fully heterogeneous $(s=0)$, cf., tables 5-8. Also, for the relatively high levels of product differentiation $(s \leq 0.4)$, an industry cartel invests more than the R\&D competitors without patent protection. However, when the level of product differentiation is not too high $(s \geq 0.5)$, the industry cartel invests less than the non-cooperating firms without a possibility of patenting.

Further, it can be seen from tables 1 through 8 that the profit of a cartel member is always higher than the profit of a non-colluding firm. Interestingly, the profit of an industry cartel member dominates the profit of an $R \& D$ cartel member for all values of $R \& D$ spillovers in the industry and most of the values of the substitutability parameter (cf., tables 5-8). The results mentioned above support the third prediction. The numerical analysis shows that for any extent of product differentiation, it is always better for the firms to create a cartel in order to maximize profits rather than to engage in $R \& D$ competition.

Lastly, by comparing tables $2,4,6$, and 8 , it can be observed that for any level of product differentiation, the $R \& D$ investments are the smallest in the case of $R \& D$ competition with patent protection (cf., figure 2). 
Figure 2. Graphical representation of the obtained results.

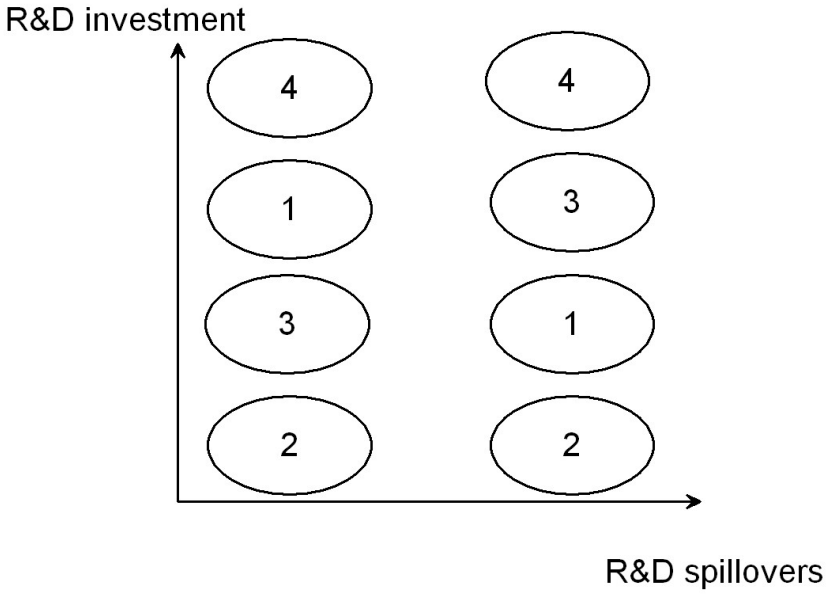

Source: own elaboration.

"1" - R\&D competition without patent protection

" 2 " - R\&D competition with patent protection

"3" - R\&D cooperation

"4" - Full industry cooperation

\section{CONCLUSIONS}

In this paper, we considered the impact of patents and $R \& D$ cooperation on R\&D investments made by firms operating in the oligopolistic market trading with differentiated products. Four types of firms' conduct in the industry were investigated: R\&D competition without patents, R\&D competition with patent protection, $R \& D$ cooperation ( $R \& D$ cartel), and the entire industry cartel (full industry cooperation). The obtained results suggest that patents do not necessarily promote R\&D investments due to the existence of so called tournament effects. R\&D cooperation seems the effective instrument which stimulates R\&D investments, but $R \& D$ cooperation provides sufficient incentives to create a full industry cartel. Such a cartel works to the detriment of consumers, since the market price under full industry cartel is higher compared with $R \& D$ competition without patents and R\&D cooperation, and the market quantity is lower under full industry cartel compared with R\&D competition without patents and R\&D cooperation.

Our comparative analysis led us to the conclusion that for a relatively low level of R\&D spillovers in the industry, the innovation policy-makers should promote R\&D competition without patent protection among oligopolistic firms. For a relatively high level of $R \& D$ spillovers, R\&D cooperation is the effective instrument which enhances corporate innovation, but the regulator should monitor the market for probable collusion. It is therefore, firms find it beneficial to extend an R\&D cartel to the full industry cartel, since the latter brings

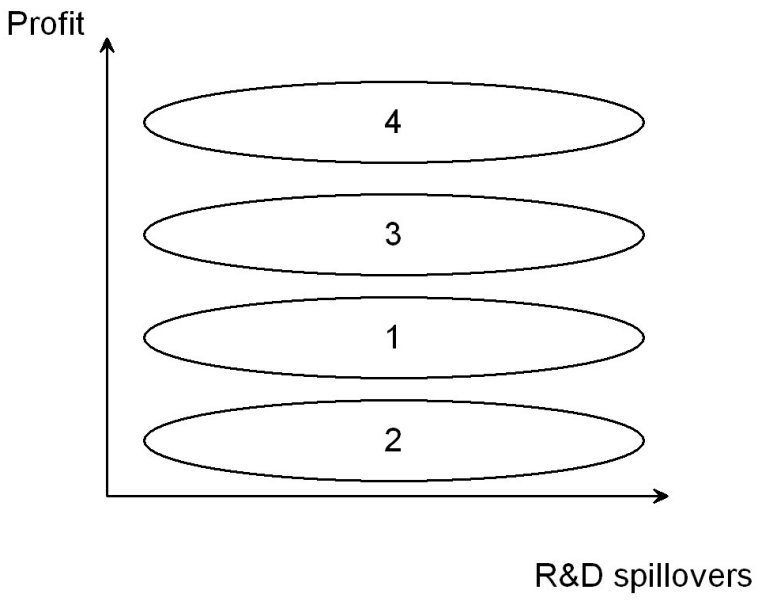

about higher corporate profits.

As regards limitations of the present study, we should be aware of the fact that the above implications for policy-makers and managers hold for Cournot competition in the product market. One needs to test the results for Bertrand, Stackelberg, and price leadership models of competition. Also, the above conclusions apply to process innovations. One needs to test the above results in the future research concerning product innovations.

\section{REFERENCES}

Abramovsky, L., Simpson, H. 2011. Geographic proximity and firm-university innovation linkages: Evidence from Great Britain. Journal of Economic Geography 11:949-977.

Arrow, K. 1962. Economic welfare and the allocation of resources to invention. In The Rate and Direction of Inventive Activity, edited by R. Nelson, 609-625. Princeton: Princeton University Press.

Aschhoff, B., Schmidt, T. 2008. Empirical evidence on the success of R\&D cooperation - happy together?. Review of Industrial Organization 33:41-62.

d'Aspremont, C., Jacquemin, A. 1988. Cooperative and Noncooperative $R \& D$ in Duopol with Spillovers. American Economic Review 78:1133-1137.

Audretsch, D., Caiazza, R. 2016. Technology transfer and entrepreneurship: cross-national analysis. The Journal of Technology Transfer 41:1247-1259. 
Baghana, R., Mohnen, P. 2009. Effectiveness of R\&D tax incentives in small and large enterprises in Québec. Small Business Economics 33:91-107.

Bagwell, K., Staiger, R. 1994. The sensitivity of strategic and corrective R\&D policy in oligopolistic industries. Journal of International Economics 36:133-150.

Barajas, A., Huergo, E., Moreno, L. 2012. Measuring the economic impact of research joint ventures supported by the EU Framework Programme. The Journal of Technology Transfer 37:917-942.

Becker, B. 2015. Public R\&D policies and private R\&D investment: A survey of the empirical evidence. Journal of Economic Surveys 29:917-942.

Becker, W. Dietz, J. 2004. R\&D cooperation and innovation activities of firms - evidence for the German manufacturing industry. Research Policy 33:209-223.

Belderbos, R., Gilsing, V., Lokshin, B., Carree, M., Sastre, J. 2018. The antecedents of new R\&D collaborations with different partner types: On the dynamics of past R\&D collaboration and innovative performance. Long Range Planning 51:285-302.

Besley, T., Suzumura, K. 1992. Taxation and welfare in an oligopoly with strategic commitment. International Economic Review 33:413-431.

Bezdrob, M., Šunje, A. 2014. Management Innovation Designing and Testing A Theoretical Model. South East European Journal of Economics and Business 9:16-29.

Bloch, C., Graversen, E. 2012. Additionality of public R\&D funding for business R\&D - A dynamic panel data analysis. World Review of Science, Technology and Sustainable Development 9:204-220.

Bloom, N., Van Reenen, J., Williams, H. 2019. A toolkit of policies to promote innovation. Journal of Economic Perspectives 33:163-184.

Boldrin, M., Levine, D. 2013. The Case Against Patents. Journal of Economic Perspectives 27:3-22.

Bravo-Ortega, C., Marin, A. 2011. R\&D and productivity: A two-way avenue?. World Development 39:1090-1107.

Carboni, O. 2011. R\&D subsidies and private R\&D expenditures: Evidence from Italian manufacturing data. International Review of Applied Economics 25:419-439.

Cassiman, B. 2000. Research joint ventures and optimal R\&D policy with asymmetric information. International Journal of Industrial Organization 18:283-314.

Chang, A. 2018. Tax policy endogeneity: evidence from R\&D tax credits. Economics of Innovation and New Technology 27:809-833.

Che, X., Yang, Y. 2009. Patent Protection with Cooperative R\&D Option. MPRA Paper No. 19436.

Chowdhury, P. 2005. Patents and R\&D: The Tournament Effect. Economics Letters 89:120-126.

Comino, S., Manenti, F., Thumm, N. 2019. The Role of Patents in Information and Communication Technologies: A
Survey of the Literature. Journal of Economic Surveys 33:404-430.

Czarnitzki, D., Toole, A. 2006. Patent protection, market uncertainty, and R\&D investment. ZEW Discussion Papers, No. 06-056, Zentrum für Europäische Wirtschaftsforschung (ZEW), Mannheim.

Czarnitzki, D., Ebersberger, B., Fier, A. 2007. The relationship between $R \& D$ collaboration, subsidies and $R \& D$ performance: Empirical evidence from Finland and Germany. Journal of Applied Econometrics 22:1347-1366.

Czarnitzki, D., Hanel, P., Rosa, J. 2011. Evaluating the impact of R\&D tax credits on innovation: A microeconometric study on Canadian firms. Research Policy 40:217-229.

David, P., Hall, B., Toole, A. 2000. Is public R\&D a complement or substitute for private R\&D? A review of the econometric evidence. Research Policy 29:497-529.

Delbono, F., Denicolo, V. 1991. Incentives to Innovate in a Cournot Oligopoly. Quarterly Journal of Economics 106:951-961.

Duguet, E. 2004. Are R\&D subsidies a substitute or a complement to privately funded R\&D? Evidence from France using propensity score methods for non-experimental data. Revue D'Economie Politique 114:263-292.

Flath, D. 2012. Are there any Cournot industries in Japan?. The Japanese Economy 39: 3-36.

Garcia-Quevedo, J. 2004. Do public subsidies complement business R\&D? A meta-analysis of the econometric evidence. Kyklos 57:87-102.

Grossman, G., Helpman, D. 1991. Innovation and Growth in the Global Economy. Cambridge, MA: MIT Press.

Guerrero, M., Urbano, D., Herrera, F. 2019. Innovation practices in emerging economies: Do university partnerships matter?. The Journal of Technology Transfer 44:615-646.

Hall, B., van Reenen, J. 2000. How effective are fiscal incentives for R\&D? A review of the evidence. Research Policy 29:449-469.

Harryson, S., Kliknaite, S., Dudkowski, R. 2007. Making innovative use of academic knowledge to enhance corporate technology innovation impact. International Journal of Technology Management 39:131-157.

Hashi, I., Stojčić, N. 2013. The impact of innovation activities on firm performance using a multi-stage model: Evidence from the Community Innovation Survey 4. Research Policy 42:353-366.

Hattori, M., Tanaka, Y. 2019. General analysis of dynamic oligopoly with sticky price. Economics Bulletin 39:2990-2998.

Hodžić, S. 2012. Research and Development and Tax Incentives. South East European Journal of Economics and Business 7:51-62.

Howitt, P., Aghion, P. 1998. Capital accumulation and innovation as complementary factors in long-run growth. Journal of Economic Growth 3:111-130. 
Jaffe, A. 1989. Real effects of academic research. American Economic Review 79:957-970.

Kafouros, M. 2005. R\&D and productivity growth: Evidence from the UK. Economics of Innovation and New Technology 14:479-497.

Kamien, M., Muller, E., Zang, I. 1992. Research Joint Ventures and R\&D Cartels. American Economic Review 82:1293-1306.

Kamien, M., Zang, I. 2000. Meet me halfway: research joint ventures and absorptive capacity. International Journal of Industrial Organization 18:995-1012.

Karbowski, A. 2019. Cooperative and non-cooperative R\&D in product innovation and firm performance. Journal of Business Economics and Management 20:1121-1142.

Karlsson, C., Andersson, M. 2009. The location of industry R\&D and the location of university R\&D - How are they related? In New Directions in Regional Economic Development. Advances in Spatial Science. Dordrecht and New York: Springer.

Kräkel, M. 2004. R\&D spillovers and strategic delegation in oligopolistic contests. Managerial and Decision Economics 25:147-156.

Leahy, D., Neary, J. 1997. Public policy towards R\&D in oligopolistic industries. American Economic Review 87:642-662.

Lokshin, B., Mohnen, P. 2012. How effective are level-based R\&D tax credits? Evidence from the Netherlands. Applied Economics 44:1527-1538.

Mahmutaj, L., Krasniqi, B. 2020. Innovation types and sales growth in small firms evidence from Kosovo. South East European Journal of Economics and Business 15:27-43.

Martin, S. 2006. Competition policy, collusion, and tacit colIusion. International Journal of Industrial Organization 24:159-176.

Mazzoleni, R., Nelson, R. 1998. The benefits and costs of strong patent protection: a contribution to the current debate. Research Policy 27:273-284.

Miyagiwa, K. 2009. Collusion and Research Joint Ventures. The Journal of Industrial Economics 57:768-784.

Mulkay, B., Mairesse, J. 2013. The R\&D tax credit in France: Assessment and ex-ante evaluation of the 2008 reform. NBER Working Paper 19073.

Nelson, R. 1959. The simple economics of basic scientific research. Journal of Political Economy 67:297-306.

Nelson, R. 1986. Institutions supporting technical advance in industry. American Economic Review 76:186-189.

Nordhaus, W. 1969. Invention, Growth and Welfare: A Theoretical Treatment of Technological Change. Chapter 5. Cambridge, MA: MIT Press.

O'Mahony, M., Vecchi, M. 2009. R\&D, knowledge spillovers and company productivity performance. Research Policy 38:35-44.

Pejic-Bach, M., Lojpur, A., Pekovic, S., Stanovčić, T. 2015. Influence of Different Information Sources to Innovation
Performance: Evidence from France, Netherlands and Croatia. South East European Journal of Economics and Business 10:89-101.

Penin, J. 2005. Patents versus ex post rewards: A new look. Research Policy 34:641-656.

Penin, J. 2012. Strategic uses of patents in markets for technology: A story of fabless firms, brokers and trolls. Journal of Economic Behavior \& Organization 84:633-641.

Petit, M., Tolwinski, B. 1999. R\&D cooperation or competition?. European Economic Review 43:185-208.

Petrin, T. 2018. A Literature Review on the Impact and Effectiveness of Government Support for $R \& D$ and Innovation. ISIgrowth Working Paper 5/2018.

Rant, M., Černe, S. 2017. Becoming a hidden champion: From selective use of customer intimacy and product leadership to business attractiveness. South East European Journal of Economics and Business 12:89-103.

Romer, P. 1986. Increasing returns and long-run growth. Journal of Political Economy 94: 1002-1037.

Scandura, A. 2016. University-industry collaboration and firms' R\&D effort. Research Policy 45:1907-1922.

Schot, J., Steinmueller, W. 2018. Three frames for innovation policy: R\&D, systems of innovation and transformative change. Research Policy 47:1554-1567.

Somaya, D. 2012. Patent Strategy and Management: An Integrative Review and Research Agenda. Journal of Management 38:1084-1114.

Stojčić, N., Srhoj, S., Coad, A. 2020. Innovation procurement as capability-building: Evaluating innovation policies in eight Central and Eastern countries. European Economic Review 121:103330.

Woodward, D., Figueiredo, O., Guimaraes, P. 2006. Beyond the Silicon Valley: University R\&D and high-technology location. Journal of Regional Science 60:15-32.

This research was supported by National Science Centre, Poland (grant number UMO-2017/25/B/ HS4/01632). 